\title{
Association between clinical and subclinical mastitis and reproductive performance of cows at Nottingham dairy centre
}

\author{
Z.A. Mohammed \\ Department of Theriogenology, Physiology and Anatomy, College of Veterinary Medicine, University of Duhok, Duhok, Iraq
}

Article information

Article history:

Received March 27, 2020

Accepted April 28, 2020

Available online March 15, 2021

\section{Keywords:}

Clinical Mastitis

Somatic cells count

Reproductive performance

Dairy cows

Correspondence:

Z.A. Mohammed

zeravantovi@gmail.com

\begin{abstract}
Clinical and subclinical mastitis regarded as important diseases causes a reduction in reproductive performance in dairy cows in the UK during the last decade. This study was aimed to assess the association between clinical mastitis, subclinical mastitis and the reproductive performance of cows. Data from 184 multiparous Holstein dairy cows were collected. Binomial logistic regression used to determine the incidence rate of clinical mastitis and subclinical mastitis between parity, calving year and seasons of the year. Linear mixed model used to determine the effect of clinical and subclinical mastitis on reproductive performance. The association between clinical or subclinical mastitis and the probability of a cow to get pregnant at 1 st, 2 nd or 3rd service was evaluated using binomial logistic regression. The same model used to illustrate the probability of a cow getting pregnant from 30-60 days postpartum or 61-90 days postpartum. The incidence of clinical mastitis was different between calving years $(\mathrm{P}<0.01)$. Cow with clinical mastitis or subclinical mastitis had longer calving to first service interval, calving to conception interval $(\mathrm{P}<0.05)$. Cows clinical mastitis had a lower rate to get pregnant within 20-30 days postpartum compared to healthy cows $(\mathrm{P}<0.05)$. Cows with higher somatic cells count, (especially cows with greater than 399,000 cells $/ \mathrm{mL}$ of milk), had a higher number of services compared to cows with a lower number of individual cow somatic cell counts. The study concluded that both clinical and subclinical mastitis have a relationship with a reduction in reproductive performance in high yielding dairy cows.
\end{abstract}

DOI: 10.33899/ijvs.2020.126843.1398, (C2021, College of Veterinary Medicine, University of Mosul.

This is an open access article under the CC BY 4.0 license (http://creativecommons.org/licenses/by/4.0/).

\section{Introduction}

Fertility in dairy herds has been declined in the UK and over the world during the last decade and regarded as a major negative factor of herd profitability (1-3). There are numerous factors that influence the reproductive performance of highly yielding dairy cows including uterine inflammation $(4,5)$ and lameness $(6,7)$. Clinical mastitis (CM) regarded as an important disease event in dairy cattle, with the recent data estimate that incidence rate of clinical mastitis in the UK ranged from 50 to 70 cases per 100 cow/years (8). The economic impact of clinical mastitis on dairy herds is associated with decreased production of milk, increased the costs of milk due to the treatment and discarded milk, decreased milk quality, with increases in somatic cell count (SCC), and increased culling rate (9). In addition to clinical mastitis, detection of subclinical mastitis in dairy herds is very problematic. Cows with subclinical mastitis look healthy, without systemic reaction, milk looks normal. It has been reported that subclinical mastitis causes a great decline in milk yield and the undetected cows would be the main causes for spreading the infection in the herd especially when the causes of mastitis is bacteria. Identification of somatic cells count in milk regarded as an accurate and indirect method for predicting the incidence of mastitis in dairy cattle. It has been documented that the level of SCC in milk does not reach $100 \times 10^{3}$ cells $/ \mathrm{ml}$ in healthy cows. However, cows considered to be sick with subclinical 
mastitis when SCC in the milk was $\geq 200 \times 10^{3}$ cells $/ \mathrm{ml}$. It has been reported that milk yield loss due to SCC was found to vary considerably depending on the level of SCC (10-12). Many previous studies have been carried out about the effect of $\mathrm{CM}$ and subclinical mastitis (SCC in milk) in high professional yielding dairy herds in the world, but the results of that studies were unclear how clinical mastitis and somatic cells count in milk have negative impact on reproductive performance in dairy cows. Recently, Hertl et al. (13) and Hudson et al. (14) have estimated the importance of the timing of clinical mastitis and its associated with a lower probability on conception. More recent studies have been tended to concentrate on the relationship between clinical mastitis and subclinical mastitis and the odds of cows become pregnant after artificial insemination. Therefore, this study aimed to evaluate the association between clinical and subclinical mastitis (somatic cells count in milk, SCC) and reproductive performance in high yielding dairy cows at Nottingham dairy centre.

\section{Material and methods}

\section{Animals}

Ethical Review Committee from The University of Nottingham approved this study, which was achieved in agreement with the UK Home Office Animal (Scientific Procedures) Act 1986 under Project Licence PPL40/1621. This study conducted on 184 multiparous Holstein dairy cows from the University of Nottingham dairy centre in the
East Midlands, UK. Data of cows that calved between 2009 and 2014 were analysed. Animals were kept in herd and managed according to normal farm practice and fed with a total mixed ration. In addition, cows were fed on concentrate fed during milking according to yield. Cows were milked by robot (Lely Astronaut A3, Adoption of automatic milking systems (AMS). All cows with udder disorders were treated according to routine farm practice with no experimental intervention.

\section{Milk samples}

Nottingham dairy centre is equipped with Lely Astronaut, AMS. Milk samples were collected from all milking per cow during a period of 24 hours on all AMS. The manufacturer's automatic sampling device was used to sample each cow for somatic cell count. Lely Astronaut A3, Adoption of automatic milking systems AMS equipped with milk quality Control-C (MQC-C) sensors were programmed to measure somatic cell count of the milk regularly. Any abnormalities in the milk which could be of concern are exposed immediately in the Lely $\mathrm{T} 4 \mathrm{C}$ management programme.

\section{Data collection}

Data from each lactation were collected from Lely T4C management programme and stored in Microsoft Excel 2010 (Microsoft Corporation, 2010). Basic statistics describing the herd is provided in Table 1.

Table1: Shows descriptive statistics for the herd used for this study

\begin{tabular}{lccccccc}
\hline Parameter & \multirow{2}{*}{ Mean } & \multirow{2}{*}{ Min. } & \multicolumn{5}{c}{ Percentile } \\
\cline { 4 - 6 } & & & $10 \%$ & $25 \%$ & $75 \%$ & $90 \%$ & Max. \\
\hline 305-day in milk (kg) & 10678 & 1540 & 6357 & 9261 & 12719 & 14454 & 18730 \\
Calving to first service interval (CFSI, d) & 57.82 & 19 & 31 & 37.25 & 71 & 95 & 170 \\
Open days (d) & 112.2 & 29 & 40.2 & 56.5 & 158 & 205.8 & 291 \\
Calving interval (CI, d) & 390.5 & 307 & 320 & 338.3 & 430.8 & 495.1 & 560 \\
ICSCC $\left(x 10^{3} / \mathrm{ml}\right)$ & 277 & 11 & 20 & 45 & 358 & 464 & 4020 \\
\hline
\end{tabular}

ICSCC=Individual cows somatic cell counted from milk-recording data which recorded form bulk milk.

For binary descriptive variables such as pregnancy outcome at $1^{\text {st }}, 2^{\text {nd }}$ or $3^{\text {rd }}$ insemination dichotomous values were used. Cases of clinical mastitis were diagnosed according to the normal practice of the herd. Incidence of mastitis was coded " 1 " for each cow and or was coded into " 0 " when cows were free from clinical mastitis. Calving to first service interval were categorised into: 20-30d; 31-60d; $61-90 \mathrm{~d}$ and $\geq 91 \mathrm{~d}$. Individual cow somatic cells (ICSCC) variables were classified into 3 categories, as presented in Table 2, to identify the detrimental effect of ICSCC on reproductive performances. Other descriptive variables were calculated in this study Table 3 . Variables such as the parity variable were recorded. Cows with parity $\geq 3$ were grouped into a single category due to low number of data.

Table 2: Individual cow somatic cell, ICSCC (cells $/ \mathrm{mL}$ ) categories

\begin{tabular}{ll}
\hline Category & Description \\
\hline 1 & $0-200,000$ \\
2 & $200,000-399,000$ \\
3 & $>399,000$ \\
\hline
\end{tabular}


Table 3: Variables (with variable type) calculated at each level of data

\begin{tabular}{ll}
\hline Variable & Variable type \\
\hline Served & Dichotomous (served or not served) \\
Become pregnant & Dichotomous (served or not served) \\
Season of year & Category (Jan-March, Apr-Jun, Jul-Sep, or Oct-Dec) \\
Parity of cow & Categorical (1, 2, or 3) \\
CM 20-30dpp & Dichotomous (case of CM recorded or not) \\
CM 31-60dpp & Dichotomous (case of CM recorded or not) \\
CM 61-90dpp & Dichotomous (case of CM recorded or not) \\
CM $\geq 91$ dpp & Dichotomous (case of CM recorded or not) \\
Milk yield $(\times 1,000 \mathrm{~kg}$ ) at 305-d & Continuous \\
ICSCC 20-30dpp & Categorical-see Table 2 \\
ICSCC31-60dpp & Categorical-see Table 2 \\
ICSCC 61-90dpp & Categorical-see Table 2 \\
ICSCC and >91dpp & Categorical-see Table 2 \\
Calving year & Categorical (2009, 2010, 2011, 2012, 2013 or 2014) \\
\hline
\end{tabular}

$\mathrm{CM}=$ Clinical mastitis; ICSCC $=$ Individual cow somatic cells count; $\mathrm{dpp}=$ day post-partum period.

\section{Statistical analysis}

The prevalence of Clinical mastitis (CM)

Binomial logistic regression (Generalized logistic regression) used to determine the prevalence of $\mathrm{CM}$ between calving years and lactation number. All statistical analysis was performed using GenStat $12^{\text {th }}$ edition (VSN International Ltd, Hemel Hempstead, UK).

The association between $\mathrm{CM}$ and subsequent reproductive performance

Linear mixed model (Wald test) used to determine the association between $\mathrm{CM}$ status (included as the factor) and reproductive performance such as CFSI, CCI, SPC, CI and $305 \mathrm{~d}$ Milk yield (included as variables). Binomial logistic regression was performed to determine the incidence rate of $\mathrm{CM}$ between lactation numbers and to evaluate the association between $\mathrm{CM}$ and the probability of a cow to get pregnant during 20-30d; 31-60d; 61-90d; or $\geq 91 \mathrm{~d}$. Moreover, binomial logistic regression used to evaluate probability of a cow becoming pregnant at $1^{\text {st }}, 2^{\text {nd }}$ or $3^{\text {rd }}$ service.

The association between ICSCC categories and the reproductive performance

Linear mixed model (Wald test) used to determine the association between ISCC categories 1, 2 or 3 status (included as the factor) and reproductive performance such as CFSI, CCI, SPC, CI and 305d Milk yield (included as the variables). Individual cow somatic cell count (ICSCC) number was recorded per each cow. Binomial logistic regression used to evaluate the association between ICSCC categories and the probability of a cow to get pregnant during 20-30d; 31-60d; 61-90d and $\geq 91 d$. Furthermore, binomial logistic regression used to evaluate the probability of a cow to get pregnant at $1^{\text {st }}, 2^{\text {nd }}$ or $3^{\text {rd }}$ service. Binomial regression was performed for determining the odds ratio of ICSCC incidence rate between parity, calving year and seasons of the year.

\section{Results}

\section{Prevalence of clinical mastitis (CM)}

The results demonstrated that the prevalence of $\mathrm{CM}$ was significantly difference among calving year $(\mathrm{P}<0.01$; Fig. 1$)$. The mean prevalence of $\mathrm{CM}$ across the whole study was $25.0 \%$. The highest incidence was observed in 2009 and the lowest rate was seen in 2014 at $39 \%$ and $10 \%$, respectively. It should be noted that this study found that the season of the year had no effect on the prevalence of $\mathrm{CM}(\mathrm{P}>0.05$, Fig.2). Moreover, this study found that no effect of lactation number on the prevalence the prevalence on $\mathrm{CM}(\mathrm{P}>0.05$; Fig. 3$)$.

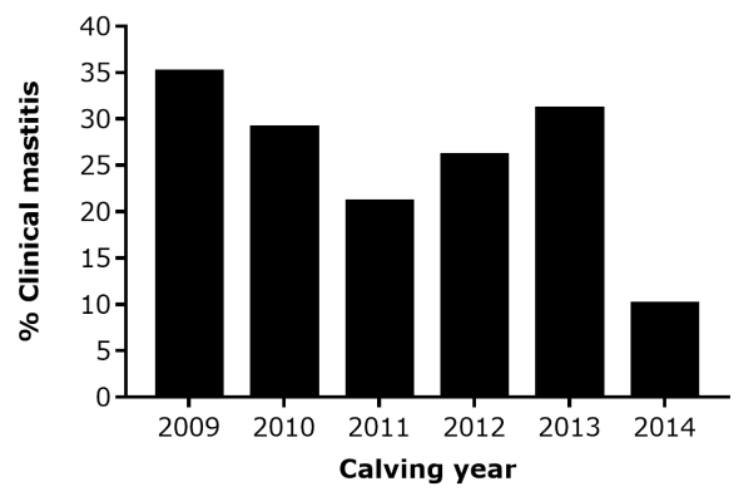

Figure 1: The prevalence of CM between years 2009 and 2014 at Nottingham dairy herds $(\mathrm{P}<0.001)$. The prevalence of CM varied from $10-39 \%$. 


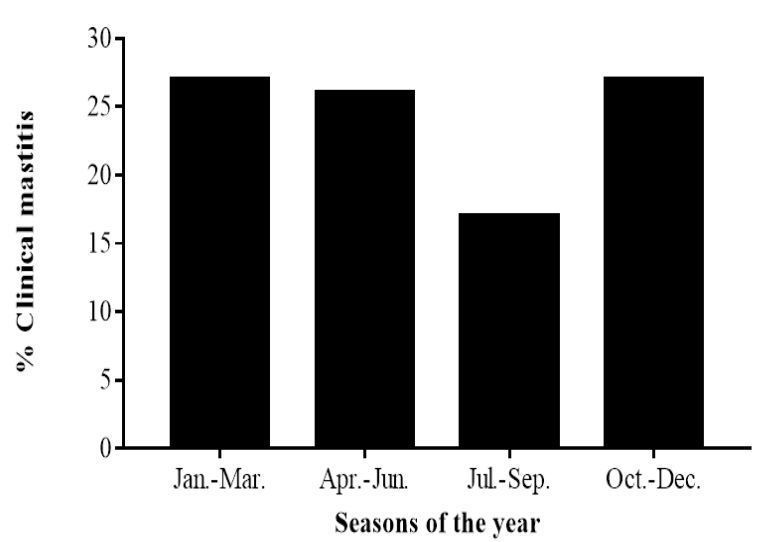

Figure 2: The prevalence of CM between seasons of the year. A) The prevalence of CM between twelve month of the year from Jan-Dec. ( $\mathrm{P}>0.05)$. B) The prevalence of $\mathrm{CM}$ between four seasons $(\mathrm{P}>0.05)$.

\section{The effect of clinical mastitis (CM) on reproductive performance}

The results showed that $\mathrm{CM}$ had impact on the reproductive performance in dairy cows. Cows with $\mathrm{CM}$ had longer calving to first service interval about 9 days $(\mathrm{P}<0.05$, Table 4). In addition, cows with $\mathrm{CM}$ had longer calving to conception interval about 21 days $(\mathrm{P}<0.05$, table 4). However, this study found no significant effect of CM on number of service per-conception and calving interval as well ( $P>0.05$, Table 4). It should be noted that this study found that $\mathrm{CM}$ had no effect on the pregnancy rate at $1^{\text {st }}, 2^{\text {nd }}$ or $3^{\text {rd }}$ services $(\mathrm{P}>0.05$, Table 4$)$. Cows with $\mathrm{CM}$ had the largest reduction in the probability of pregnancy about $13 \%$ in the period from 20-30dpp, when the case of CM being evaluated $(\mathrm{P}<0.01$, Table 4$)$. However, this study found that there was no such relationship was identified for the probability of pregnancy during 31-60dpp; 61-90dpp and $>90 \mathrm{dpp}$ relating to $\mathrm{CM}$ cases $(\mathrm{P}>0.05$, Table 4$)$.

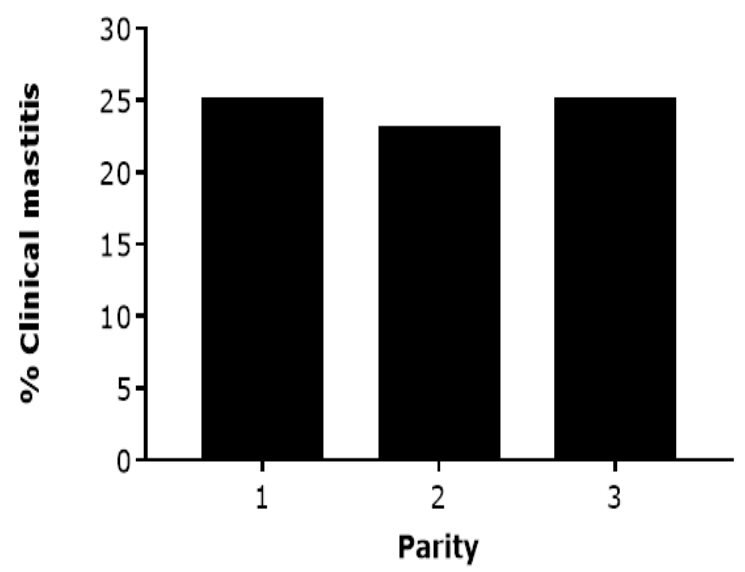

Figure 3: The Incidence rate of CM between parity. No significant difference of CM incidence seen between parity $(\mathrm{P}>0.05)$.

Logistic regression showed that year of calving, the season of the year, did not affect the incidence of subclinical mastitis in high yielding dairy cows at Nottingham dairy centre $(\mathrm{P}>0.05)$, Table 5 . This study found that parity 1 and 3 did not affect the incidence of subclinical mastitis. However, this study showed that as the odds ratio of parity 2 decreased the incidence rate of subclinical mastitis decreased significantly $(\mathrm{P}<0.05)$, Table 5 . It should be noted that subclinical mastitis did not affect on $305 \mathrm{~d}$ milk yield $(\mathrm{P}>0.05)$ (Figure 4).

Table 4: Association between CM and the reproductive performance in high yielding dairy cows during postpartum period

\begin{tabular}{lccc}
\hline Reproductive parameter & No.CM $($ Mean \pm SE) & CM (Mean \pm SE) & P value \\
\hline Calving to first service interval (d) & $51.8 \pm 3.0$ & $60.8 \pm 2.6$ & 0.02 \\
Calving to conception interval (d) & $98.8 \pm 7.5$ & $121.3 \pm 6.4$ & 0.024 \\
Number of service per conception (n) & $2.51 \pm 0.2$ & $2.66 \pm 0.2$ & 0.536 \\
Calving interval (d) & $383.6 \pm 11.7$ & $393.3 \pm 9.0$ & 0.51 \\
\hline $1^{\text {st }}$ service pregnancy rate (\%) & $31.6 \%$ & $26.2 \%$ & 0.435 \\
$2^{\text {nd }}$ service pregnancy rate (\%) & $21.1 \%$ & $21.4 \%$ & 0.961 \\
$3^{\text {rd }}$ service pregnancy rate (\%) & $18.4 \%$ & $17.5 \%$ & 0.871 \\
Cows become pregnant in 20-30 dpp & $15.8 \%$ & $2.9 \%$ & 0.002 \\
Cows become pregnant in 31-60 dpp & $54.0 \%$ & $62.4 \%$ & 0.274 \\
Cows become pregnant in 61-90 dpp & $21.1 \%$ & $25.2 \%$ & 0.516 \\
Cows become pregnant in >90 dpp & $9.2 \%$ & $9.7 \%$ & 0.911 \\
\hline
\end{tabular}

Note: The data presented in this table were compared between healthy cows and cows with clinical mastitis

Cows with subclinical mastitis $(\geq 200,000$ cells $/ \mathrm{ml})$ had 703L more milk but statistically not different. This study found that ICSCC categories 2 and 3 were associated with longer CFSI compared to category 1 about 16, 26 days, respectively $(\mathrm{P}<0.01$, Table 6). Furthermore, ICSCC categories 2 and 3 were associated with longer open days 
compared to category 1 about 9, 33 days, respectively $(\mathrm{P}<0.05$, Table 6). In addition, this study found that ICSCC categories 2 and 3 had a higher number of services compared with category 1 about $0.3,1.1$ respectively $(\mathrm{P}<0.01$, Table 5). However, ICSCC categories did not have effect on pregnancy rate at 1,2 and 3 with $1^{\text {st }}, 2^{\text {nd }}$ and $3^{\text {rd }}$ service (P>0.05, Table 6). Individual SCC categories 1, 2 and/or 3 had no effect on the probability of cows to become pregnancy during 30-60dpp and 61-90 dpp (P>0.05, Table $6)$.

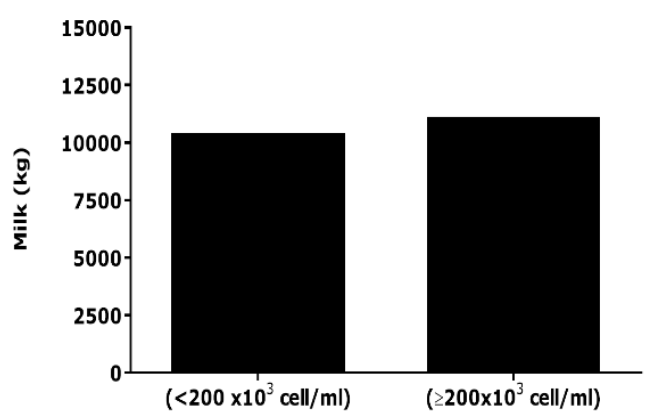

Figure 4: The effect of subclinical mastitis on $305 \mathrm{~d}$ milk yield.

Table 5: Parameters estimate the effects of different factors on the incidence of subclinical mastitis ICSCC ( $\geq 200,000$ cells/ml)

\begin{tabular}{|c|c|c|c|c|c|}
\hline \multirow{2}{*}{ Factors } & \multirow{2}{*}{ Parameter estimate $\pm \mathrm{SE}$} & \multicolumn{3}{|c|}{$95 \%$ Wald CI } & \multirow{2}{*}{ P-value } \\
\hline & & odds ration & Lower & Upper & \\
\hline \multicolumn{6}{|l|}{ Parity } \\
\hline 1 & & 1 & \multicolumn{2}{|c|}{ Reference } & 0.17 \\
\hline 2 & $-0.83 \pm 0.36$ & 0.4364 & 0.2154 & 0.8842 & 0.02 \\
\hline 3 & $-0.40 \pm 0.36$ & 0.6734 & 0.3314 & 1.368 & 0.27 \\
\hline \multicolumn{6}{|c|}{ Year of calving } \\
\hline 2010 & & 1 & \multicolumn{2}{|c|}{ Reference } & \\
\hline 2011 & $-0.25 \pm 0.59$ & 0.78 & 0.24 & 2.50 & 0.68 \\
\hline 2012 & $-0.03 \pm 0.55$ & 0.97 & 0.33 & 2.83 & 0.96 \\
\hline 2013 & $-0.48 \pm 0.54$ & 0.62 & 0.21 & 1.80 & 0.38 \\
\hline 2014 & $-0.93 \pm 0.58$ & 0.39 & 0.13 & 1.22 & 0.11 \\
\hline \multicolumn{6}{|c|}{ Season of year } \\
\hline 1 (Jan-Mar) & & 1 & \multicolumn{2}{|c|}{ Reference } & \\
\hline 2 (Ape-Jun) & $0.04 \pm 0.52$ & 1.04 & 0.38 & 2.86 & 0.93 \\
\hline 3 (Jul-Sep) & $-0.67 \pm 0.42$ & 0.51 & 0.23 & 1.16 & 0.11 \\
\hline 4 (Oct-Dec) & $-0.25 \pm 0.48$ & 0.78 & 0.31 & 1.97 & 0.59 \\
\hline
\end{tabular}

Table 6: Reproductive performance among different ICSCC categories

\begin{tabular}{lcccl}
\hline \multirow{2}{*}{ Reproductive performance } & \multicolumn{3}{c}{ ICSCC categories (Mean \pm SE) } & \multirow{2}{*}{ P-value } \\
\cline { 2 - 4 } & 1 & 2 & 3 & \\
\hline Calving to first service interval (d) & $48.4 \pm 2.59^{\mathrm{a}}$ & $64.19 \pm 3.44^{\mathrm{b}}$ & $73.6 \pm 4.3^{\mathrm{c}}$ & $<0.001$ \\
Calving to conception interval (d) & $103.4 \pm 6.64^{\mathrm{a}}$ & $112.8 \pm 8.80^{\mathrm{ab}}$ & $136.2 \pm 11.20^{\mathrm{b}}$ & 0.045 \\
Number of service per conception & $2.3 \pm 0.16^{\mathrm{a}}$ & $2.6 \pm 0.2^{\mathrm{ab}}$ & $3.4 \pm 0.3^{\mathrm{c}}$ & 0.001 \\
Calving interval (d) & $387.5 \pm 10.0$ & $386.2 \pm 12.3$ & $404.2 \pm 15.1$ & 0.598 \\
1st service pregnancy rate & $28.4 \%$ & $31.5 \%$ & $25.7 \%$ & 0.838 \\
2nd service pregnancy rate & 25.3 & $16.7 \%$ & $20.0 \%$ & 0.46 \\
3rd service pregnancy rate & $14.7 \%$ & $14.8 \%$ & $31.4 \%$ & 0.069 \\
Cows become pregnant in 31-60 dpp & $14.5 \%$ & $16.0 \%$ & $15.3 \%$ & 0.597 \\
Cows become pregnant in 61-90 dpp & $19.6 \%$ & $22.0 \%$ & $22.0 \%$ & 0.596 \\
\hline
\end{tabular}

Different letters a,b,c at the same rows were significant $(\mathrm{P}<0.05)$, ab were not significant $(\mathrm{P}>0.05)$.

\section{Discussion}

The present study agrees with the previous works in the same filed reporting that both CM and ICSCC could have substantial effect on the reproductive performance in high yielding dairy cows during the post-partum period at Nottingham dairy centre. The incidence rate of clinical mastitis in this study during 305-day was about $25.0 \%$, which has impact on the reproductive performance during postpartum period. This incidence rate of CM is nearly about 
the same rate $26.9 \%$ reported by Hertl et al. (13) in Turkey and $23 \%$ recoded by Hudson et al. (14) in France. However, it is lower than $40 \%$ that estimated in England during 19941996 (15) and 37.5\% was estimated in Salahaldeen province (16). Furthermore, this incidence is much lower that reported in than reported in England and wales 2007 (8). The low incidence of CM in this study may be due to inadequate data used in this study compared to previous studies carried out in England and Wales.

The current study investigated that variables such as parity, seasons of the years did not effect on the incidence of the CM. This is parallel to Lescourret et al. (17) reported that lactations number and seasons of the years were associated with the incidence rate of CM. It should be noted this study reported that the year of calving had associated with the incidence rate of CM. Disagreement with the previous study carried out by Lescourret et al. (17), who used data from the large number of dairy herds across UK, they found that there was no relation between calving years and the incidence of $\mathrm{CM}$. Regarding to overall reproductive performance, CM had substantial association to reduced reproductive performance of high yielding dairy at Nottingham dairy centre. Cows with $\mathrm{CM}$ had longer calving to first service interval, calving to conception interval. Furthermore, CM had association with a lower probability of cows becoming pregnant from 20-30 dpp. This is parallel to the previous studies that cows with $\mathrm{CM}$ had longer days to first insemination interval; longer open days (18-22). It has been reported that cows producing milk more 21 litter/days had significantly longer calving interval and had more services per conception (23).

The mechanism by which CM effect on delay day to first service interval and longer calving to conception interval is might be due to affect hypothalamic-pituitary-ovary hormonal axis (24) and resulting delay onset of ovarian activity $(25,26)$. Mohammed (5) investigated that metritis delay onset of post-partum ovarian cyclicity in high yielding dairy cow at Nottingham dairy centre. Metritis increased abnormal progesterone profile particularly and consequently delayed onset of post-partum ovarian cyclicity. It is interesting to note that cows with metritis had smaller corpus luteum and produced low amount of P4 (27). It has been reported that cows with $\mathrm{CM}$ experienced to suppression of LH surge which cause delay ovulation or increased PGF $2 \alpha$ which cause decreased $\mathrm{P} 4$ production this may cause the follicles failure to develop (28). Lescourret et al. (17) demonstrated that cows with $\mathrm{CM}$ caused by $S$. uberis cause the uterus to be sensitive to release PGF $2 \alpha$ during luteal phase and this lead to decrease reproductive efficiency through reducing the luteal phase by decreasing embryo development.

Lescourret et al. (17) reporetd that CM was associated with reduced pregnancy rate during 70 days after service. The causes of cows with CM to get pregnant during this time is might be related to the management decisions not to serve a cow with CM, or might be related to suppress of ovulation or failure a cow to return to oestrus cycle. This study found that the rate of subclinical mastitis $(\geq 200,000$ cells/ml $)$ was not different among calving year, season of the year and even parity 1 and 3 . However, this study demonstrated that cows with parity 2 had lower incidence rate of subclinical mastitis. The mechanism behind this phenomenon is fully understood, but this is could be due to the low number of data or may be associated with the functions of the leukocytes with increasing the age of the cow.

In accordance with previous studies (17,29-31) they reported that parity increased the incidence of subclinical mastitis in high yielding dairy cows. The present study reported that cows with subclinical mastitis $(\geq 200,000$ cells $/ \mathrm{ml}$ ) produced more $305 \mathrm{~d}$ milk, but the effect was moderate and was not statistically significant. The relationship between subclinical mastitis (ICSCC $\geq 200,000$ cells $/ \mathrm{ml}$ ) and overall reproductive performance in high yielding dairy cows are generally supported by previous works and provide new information in terms the timing of subclinical mastitis. It should be noted that the present study used ICSCC as a proxy for subclinical mastitis, and data for cows with $\mathrm{CM}$ are also included in the study. Therefore, this study will represent the results as the association between subclinical mastitis (ICSCC $\geq 200,000$ cells $/ \mathrm{ml}$ ) and reproductive performance.

The present study demonstrated that cows with ICSCC category 3 had significantly longer interval for calving to first service interval and calving to conception interval by about 10 and 25 days compared to ICSCC categories 2 and 1, respectively. In accordance with Santons et al. (22) that cows with subclinical mastitis (as diagnosed by bacteriological sampling) had longer calving-to-conception interval. However, the same study did not find significant effect of subclinical mastitis on either first service pregnancy rate diagnosis or later in lactation (22). The present study reported that cows with subclinical mastitis (ICSCC $\geq 200.000$ cells $/ \mathrm{ml}$ ) have effect on the number of service per conception. This indicates that subclinical mastitis has a substantial relationship with reproductive performance in high yielding dairy cows. Cows with ICSCC category 3 (ICSCC $\geq 399.000$ cells $/ \mathrm{ml}$ ) had 1.1 more service per conception. Similarly to the previous study Lescourret et al. (17) demonstrated the odds of service leading to pregnancy decreased $18 \%$ with increased ICSCC from 200,000 and 399,000 cells $/ \mathrm{mL}$, however, the odds were decreased significantly by about $26 \%$ in cows with ICSCC $>399,000$ cells $/ \mathrm{ml}$. There are many different mechanisms have been reviewed to clarify the effect of udder health on reproductive outcomes in high yielding dairy cows. These mechanisms are widely studied by Schrick et al. (24), but mostly involve the negative influence of inflammatory mediators on ovarian follicular function $(32,33)$, ovarian activity $(5,34)$ and luteal function (25), embryonic survival in the uterus (35), and the balance between PGF $2 \alpha$ and PGE2 $\alpha$ after conception (36). 
In this study, both clinical and subclinical mastitis extended calving to conception interval were could be more associated with ovarian function. It should be noted that the date were used in the this study could be lower than been used in the previous studies for example, study performed by Lescourret et al. (17) they used data form the large scale herds in the UK. This study used date from a herd where could be managed more carefully compared with dairy herds of UK as a whole. The sizeable body of work examining the possible mechanisms through which $\mathrm{CM}$ and subclinical mastitis could affect fertility outcome in dairy cow already exists, and this could help researchers to determine the suitable methods such as therapy for minimizing the effect of this udder health on dairy cows.

\section{Conclusions}

The present study concluded that relationship between both $\mathrm{CM}$ and subclinical mastitis and decreased reproductive performance in high yielding dairy cows. Cows with CM and subclinical mastitis need longer time to return their ovarian cyclicity and had longer calving to conception interval with a higher number of services per-conception especially in subclinical mastitis cases. So this study concluded that it is essential to examine cows for both $\mathrm{CM}$ and subclinical mastitis during the first 30dpp to reduce the incidence rate mastitis and subclinical mastitis in the herd.

\section{Acknowledgements}

This study was funded by the Ministry of higher education and scientific research, Kurdistan Regional Government, Iraq. The author would also like to thank associated professor Dr. Bob Robinson and associated Professor Dr. George Mann for their role for conducting the data and helping me in the designing of this study. The author wants to thank the staffs at Nottingham dairy centre for conducting the data collection.

\section{Conflict of interest}

The author declares no conflict of interest

\section{References}

1. Esslemont RJ, Kossaibati MA, Allcock J. Economics of fertility in dairy cows. BSAP 2001;26(1):19-29. DOI: 10.1017/S0263967X00033565

2. LeBlanc SJ. Postpartum uterine disease and dairy herd reproductive performance: a review. Vet J. 2008: 176(1):102-14. DOI: $10.1016 /$ j.tvjl.2007.12.019

3. Hudson CD, Breen JE, Bradley AJ, Green MJ. Fertility in UK dairy herds: preliminary findings of a large-scale study. Cattle Pract. 2010;18 (2):89-94. [available here]

4. Robert OG. The effects of endometritis on the establishment of pregnancy in cattle. Reprod Fertil Develop. 2011;24(1):252-257. DOI: $\underline{10.1071 / R D 11915}$
5. Mohammed ZA, Mann GE, Robinson RS. Impact of endometritis on post-partum ovarian cyclicity in dairy cows. Vet J. 2019;248:8-13. DOI: $10.1016 / j . t v j 1.2019 .03 .008$

6. Mellado M, García JE, Véliz Deras FG, deSantiago MDIÁ, Mellado J, Gaytán LR, Ángel-García O. The effects of periparturient events, mastitis, lameness and ketosis on reproductive performance of Holstein cows in a hot environment. Aust J Vet Sci. 2018;50(1):1-8. DOI: 10.4067/S0719-81322018000100102

7. Sadiq MB, Ramanoon SZ, Shaik Mossadeq, WM, Mansor R, SyedHussain, SS. Association between lameness and indicators of dairy cow welfare based on locomotion scoring, body and hock condition, leg hygiene and lying behaviour. Anim. 2017;7(11):79. DOI: $10.3390 /$ ani7110079

8. Bradley A, Leach K, Breen J, Green L, Green M. Survey of the incidence and etiology of mastitis on dairy farms in England and Wales. Vet Record. 2007;(160):253-258. DOI: 10.1136/vr.160.8.253

9. DeGraves FJ, Fetrow J. Economics of mastitis and mastitis control. Vet Clin N Am Food Anim Pract. 1993;9(3):421-434. DOI: 10.1016/s0749-0720(15)30611-3

10. Philipsson J, Ral G, Berglund B. Somatic cell count as a selection criterion for mastitis resistance in dairy cattle. Livestock Prod Sci. 1995;41(3):195-200. DOI: 10.1016/0301-6226(94)00067-H

11. Sender G, Lukaszewicz M, Dorynek Z, Rosochowicz L. Genetic evaluation of somatic cell count in fresian cows from north-west Poland. Anim Sci Papers Rep. 1998;16:19-23. DOI: 10.3168/jds.S0022-0302(94)77154-X

12. Rupp R, Boichard D. Relationship of early first lactation somatic cell count with risk of subsequent first clinical mastitis. Livestock Prod Sci. 2000;62(2):169-180. DOI: 10.1016/S0301-6226(99)00056-1

13. Hertl J, Gröhn Y, Leach J, Bar D, Bennett G, Gonzalez R, Rauch B, Welcome F, Tauer L, Schukken Y. Effects of clinical mastitis caused by gram-positive and gram-negative bacteria and other organisms on the probability of conception in New York State Holstein dairy cows. J Dairy Sci. 2010;93(4):1551-1560. DOI: 10.3168/jds.2009-2599

14. Hudson CD, Bradley AJ, Breen JE, Green MJ. Associations between udder health and reproductive performance in United Kingdom dairy cows. J Dairy Sci. 2012;95(7):3683-3697. DOI: 10.3168/jds.2011-4629

15. Boujenane I, El-Aimani J, Kahlid BY. Incidence and occurrence time of clinical mastitis in Holstein cows. Turkish J Vet Anim Sci. 2015;39:42-49. DOI: 10.3906/vet-1401-107

16. Lescourret F, Coulon J, Faye B. Predictive model of mastitis occurrence in the dairy cow. J Dairy Sci. 1995;78:2167- 2177. DOI: 10.3168/jds.S0022-0302(95)76844-8.17

17. Kossaibati M, Hovi M, Esslemont R. Incidence of clinical mastitis in dairy herds in England. Vet Record. 1998;143:649-653. DOI: 10.1136/vr.143.24.649

18. Noomi BS. Detection of virulence factors of Pseudomonas aeruginosa in different animals by using bacteriological and molecular methods. Iraqi J Vet Sci. 2018:32(2):205-210. DOI: 10.33899/ijvs.2019.153851

19. Kumar N, Manimaran A, Sivaram M, Kumaresan A, Jeyakumar S, Sreela L, Mooventhan P, Rajendran D. Influence of clinical mastitis and its treatment outcome on reproductive performance in crossbred cows: A retrospective study. Vet World. 2017;10(5):485. DOI: 10.14202/vetworld.2017.485-492

20. Nava-Trujillo H, Soto-Belloso E, Hoet AE. Effects of clinical mastitis from calving to first service on reproductive performance in dualpurpose cows. Anim Reprod Sci. 2010;121(1-2):12-16. DOI: 10.1016/j.anireprosci.2010.05.014

21. Barker A, Schrick F, Lewis M, Dowlen H, Oliver S. Influence of clinical mastitis during early lactation on reproductive performance of Jersey cows. J Dairy Sci. 1998;81(5):1285-1290. DOI: 10.3168/jds.S0022-0302(98)75690-5

22. Santos J, Cerri R, Ballou M, Higginbotham G, Kirk J. Effect of timing of first clinical mastitis occurrence on lactational and reproductive performance of Holstein dairy cows. Animal Reprod Sci. 2004;80(12):31-45. DOI: 10.1016/S0378-4320(03)00133-7

23. Neuvians T, Schams D, Berisha B, Pfaffl M. Involvement of proinflammatory cytokines, mediators of inflammation, and basic fibroblast growth factor in prostaglandin F2 $\alpha$-induced luteolysis in 
bovine corpus luteum. Biol Reprod. 2004;70 (2):473-480. DOI: 10.1095/biolreprod.103.016154

24. Schrick F, Hockett M, Saxton A, Lewis M, Dowlen H, Oliver S. Influence of subclinical mastitis during early lactation on reproductive $\begin{array}{lll}\text { parameters. J Dairy Sci. 2001;84(6):1407-1412. DOI: } & \end{array}$ 10.3168/jds.S0022-0302(01)70172-5

25. Hansen PJ, Soto P, Natzke RP. Mastitis and fertility in cattle- possible involvement of inflammation or immune activation in embryonic mortality. American J Reprod Immunol. 2004;51(4):294-301. DOI: 10.1111/j.1600-0897.2004.00160.x

26. Huszenicza G, Janosi S, Kulcsar M, Korodi P, Dieleman S, Bartyik J, Rudas, P, Ribiczei-Szabó P. Gram-negative mastitis in early lactation may interfere with ovarian and certain endocrine functions and metabolism in dairy cows. Reprod Domestic Anim. 1998;33(3-4):147153. DOI: $10.1111 / \mathrm{j} .1439-0531.1998 . t b 01333 . x$

27. Moore D, Cullor JS, Bondurant R, Sischo W. Preliminary field evidence for the association of clinical mastitis with altered interestrus intervals in dairy cattle. Theriogenol. 1991;36(2):257-265. DOI: 10.1016/0093-691X(91)90384-P

28. Mohammed ZA, Robinson RS, Harris R, McLaughlin Y, Turnbull KE, Mann G, Woad KJ. Detrimental effects of uterine disease and lipopolysaccharide on luteal angiogenesis. $\mathrm{J}$ Endocrinol. 2020;245(1):79-92. DOI: 10.1530/JOE-19-0443

29. Savio J, Thatcher W, Morris G, Entwistle K, Drost M, Mattiacci M. Effects of induction of low plasma progesterone concentrations with a progesterone-releasing intravaginal device on follicular turnover and fertility in cattle. Reprod. 1993;98(1):77-84. DOI: 10.1530/jrf.0.0980077

30. Hiitiö H, Vakkamäki J, Simojoki H, Autio T, Junnila J, Pelkonen S, Pyörälä S. Prevalence of subclinical mastitis in Finnish dairy cows: changes during recent decades and impact of cow and herd factors. Acta Vet Scan. 2017;59:(22):1-14. DOI: 10.1186/s13028-017-0288-x

31. Hagnestam-Nielsen C, Emanuelson U, Berglund B, Strandberg E. Relationship between somatic cell count and milk yield in different stages of lactation. J Dairy Sci. 2009;92(7):3124-3133. DOI: 10.3168/jds.2008-1719

32. Reksen O, Sølverød L, Osteras O. Relationships between milk culture results and composite milk somatic cell counts in Norwegian dairy cattle. J Dairy Science. 2008;91(8):(3102-3113). DOI: $10.3168 /$ jds.2008-1006

33. Herath S, Williams EJ, Lilly ST, Gilbert RO, Dobson H, Bryant CE, Sheldon IM. Ovarian follicular cells have innate immune capabilities that modulate their endocrine function. Reprod. 2007;134 (5):683-693. DOI: 10.1530/REP-07-0229

34. Williams EJ, Sibley K, Miller AN, Lane EA, Fishwick J, Nash DM, Herath S, England GC, Dobson H, Sheldon IM. The effect of Escherichia coli lipopolysaccharide and tumour necrosis factor alpha on ovarian function. Am J Reprod Immunol. 2008;60(5):462-473. DOI: 10.1111/j.1600-0897.2008.00645.x

35. Mohammed ZA. Mechanisms of fertility failure in high yielding dairy cows [PhD dissertation]. Nottingham: University of Nottingham; 2016. $72-85$ p. [available here]

36. Soto P, Natzke R, Hansen P. Identification of possible mediators of embryonic mortality caused by mastitis: actions of lipopolysaccharide, prostaglandin F2 $\alpha$, and the nitric oxide generator, sodium nitroprusside dihydrate, on oocyte maturation and embryonic development in cattle. Am J Reprod Immunol. 2003;50(3):263-272. DOI: 10.1034/j.16000897.2003.00085.x

\section{الارتباط بين التهاب الضرع السريري وعدد الخلايا

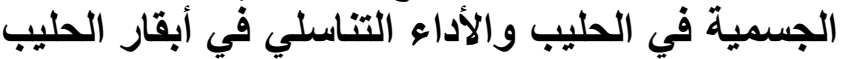 العالية الإنتاج في مركز نوتنغهام للألبان}

زيرفان عبدالرزاق محمد

$$
\text { فرع علم تناسل الحيوان و الفسلجة والتشريح، كلية الطب البيطري، جامعة }
$$

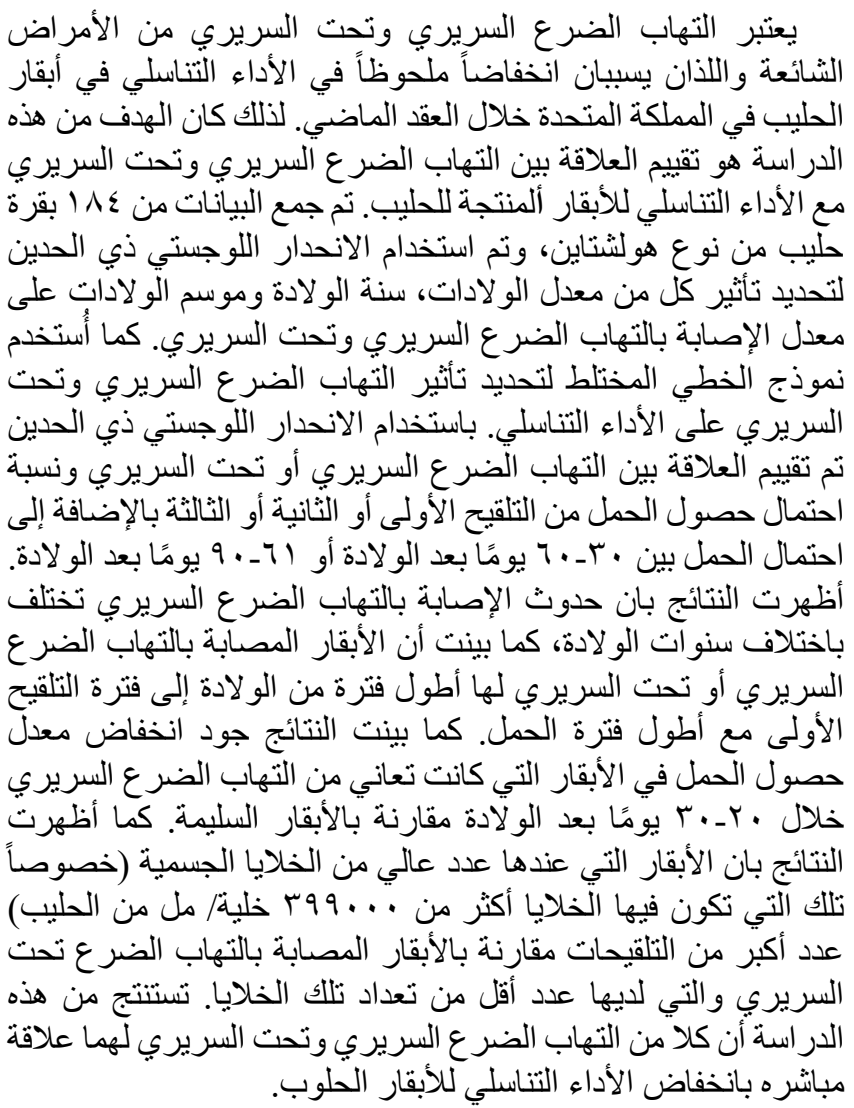

